\title{
Poetry and Philosophy in the Sophists
}

\author{
Poesía y filosofía en los sofistas
}

\author{
William Allan ${ }^{1}$ \\ University College, Oxford (Reino Unido)
}

Recibido:19-09-19

Aprobado: 15-06-20

\begin{abstract}
This paper examines the relationship between poetry and philosophy in the sophists, asking what role earlier traditions of poetry and song played in their work. The sophists' influence on various genres of literature and philosophy is widely acknowledged, but, as this paper shows, the influence of earlier traditions of poetry and myth on their work was no less important. The paper demonstrates too how the sophists' engagement with the poetic tradition, like that of the Presocratics, was geared primarily to serve their philosophical or didactic goals, even if the aesthetic benefits of poetic language and style were also appreciated and exploited. Moreover, the sophists recognized poetry's important role in education, and their varied use of poetic language, style, and content in their own teaching was a continuation of this traditional aspect of poetry. In conclusion, the sophists' work on rhetorical, political, and ethical issues engaged with, and was enriched by, the shared poetic culture of their time.
\end{abstract}

Key-words: Sophists, Presocratics, Poetry, Philosophy, Greece.

\section{Resumen}

Este artículo examina la relación entre poesía y filosofía en los sofistas, preguntando qué papel jugaron las tradiciones anteriores de poesía y canto

\footnotetext{
${ }^{1}$ (william.allan@univ.ox.ac.uk) McConnell Laing Fellow and Tutor in Classics at University College, Oxford. His publications include Greek Elegy and Iambus: A Selection (Cambridge University Press, 2019); Moralizing Strategies in Early Greek Poetry (Co-Editor, Mouseion LIX, University of Toronto Press, 2018); Homer: The Odyssey (Introduction and Notes, Oxford World's Classics, 2016); Classical Literature: A Very Short Introduction (Oxford University Press, 2014).

ORCID: https://orcid.org/0000-0003-3582-3616.
} 
en su obra. La influencia de los sofistas en varios géneros de literatura y filosofía es ampliamente reconocida, pero, como muestra este artículo, la influencia de las tradiciones anteriores de poesía y mito en su obra no fue menos importante. El artículo demuestra también cómo el compromiso de los sofistas con la tradición poética, como la de los presocráticos, se orientó principalmente en pos de sus objetivos filosóficos o didácticos, aun cuando los beneficios estéticos del lenguaje poético y del estilo también fueran apreciados y explotados. Los sofistas, además, reconocieron el importante papel de la poesía en la educación, y el uso variado del lenguaje poético, el estilo y el contenido en su propia enseñanza era una continuidad de ese aspecto tradicional de la poesía. En conclusión, la obra de los sofistas en cuestiones retóricas, políticas y éticas se relacionó y enriqueció con la cultura poética compartida de su tiempo.

Palabras-clave: sofistas, presocráticos, poesía, filosofía, Grecia.

\section{Introduction: the sophists as performers of wisdom}

The influence of the sophists on various genres of Classical Greek literature - especially tragedy, comedy, history, and philosophy - and their varied reception therein, from the rhetoric and Realpolitik of Thucydides to the comic anti-intellectualism of Aristophanes or outright hostility of Plato, has been extensively studied. ${ }^{2}$ My aim here, by contrast, is to study the relationship between the sophists and the Greek literary tradition in the opposite (and not so familiar) direction, asking what role earlier traditions of poetry and song played in the sophists' own work - in other words, I shall be considering what the sophists themselves did with the literary genres that preceded them rather than what historians, dramatists, and philosophers did with them. Unlike the Presocratic thinkers Xenophanes, Parmenides, and Empedocles, the sophists

${ }^{2}$ For example, K.J. Dover, Aristophanes: Clouds (Oxford, 1968), xxxvii-xl, W.K.C. Guthrie, The Sophists (Cambridge, 1971), 14-26, J. de Romilly, The Great Sophists in Periclean Athens, trans. J. Lloyd (Oxford, 1992), 1-29, D.M. MacDowell, Aristophanes and Athens (Oxford, 1995), 125-33, D.J. Conacher, Euripides and the Sophists: Some Dramatic Treatments of Philosophical Ideas (London, 1998), C. Carey, 'Old comedy and the sophists', in F.D. Harvey and J. Wilkins (edd.), The Rivals of Aristophanes: Studies in Athenian Old Comedy (London, 2000), 255-64, R. Thomas, Herodotus in Context: Ethnography, Science and the Art of Persuasion (Cambridge, 2000), 122-34, 250-69, G.J. Pendrick, Antiphon the Sophist: The Fragments (Cambridge, 2002), 53-67, M. McCoy, Plato on the Rhetoric of Philosophers and Sophists (Cambridge, 2008), S. Hornblower, 'Intellectual affinities', in J. S. Rusten (ed.), Oxford Readings in Classical Studies: Thucydides (Oxford, 2009), 60-88, D. Corey, The Sophists in Plato's Dialogues (Albany, 2015). For references to the sophists in tragedy and comedy, see also the passages collected in A. Laks and G.W. Most, Early Greek Philosophy, Vol. IX: Sophists, Part II (Cambridge, MA, 2016), 256-365. 
did not communicate their major scientific and philosophical ideas in verse. ${ }^{3}$ Nonetheless, some of the sophists composed poetry and all were deeply indebted to the poetic traditions of their time. ${ }^{4}$

Proper understanding of the sophists' achievements has long been hampered by their biased presentation in ancient sources. Their negative portrayal by Aristophanes, Xenophon, Plato, and Aristotle ensured that from the outset the word sophist carried connotations of charlatanism and dishonest verbal trickery. Their rehabilitation began in the nineteenth century, when Hegel and Grote rejected such critical views, and since then the sophists have gradually emerged as more than the spurious and superficial figures depicted by the tradition. ${ }^{5}$ In truth a sophist like Protagoras had as much right as any other Greek thinker to the title philosophos ('lover of wisdom'). ${ }^{6}$ Yet by appropriating the term 'philosophy' for his own specialized discipline, and by forming it in opposition to the allegedly bogus wisdom of the sophists (and poets), ${ }^{7}$ Plato ensured that the sophists were seen as 'lovers of cash'8 rather than 'lovers of wisdom'?

The traditional (dismissive) view of the sophists has led to many distortions: most strikingly, perhaps, it has obscured the continuities between their interests and those of the Presocratics. However, it is more illuminating to view the

3 On verse as a medium of Presocratic philosophy, see E. Hussey, The Presocratics (London, 1972), 78-81, C. Osborne, 'Was verse the default form for Presocratic philosophy?', in C. Atherton (ed.), Form and Content in Didactic Poetry (Bari, 1998), 23-35, S. Goldhill, The Invention of Prose (Oxford, 2002), 3-4, J. Warren, Presocratics (Abingdon, 2007), 11-12.

${ }^{4}$ Antiphon is said to have written tragedies ([Plut.] $X$ orat. 833c); Hippias epics, tragedies, dithyrambs, and elegies (Pl. Hp. mi. 368c-d, Paus. 5.25.4); and Socrates (who, despite not charging for his teaching, shared many of the sophists' intellectual interests) a hymn to Apollo and Artemis and an Aesopic fable in verse (Suda 2.829 Adler).

5 See G.B. Kerferd, The Sophistic Movement (Cambridge, 1981), 4-14 for a concise history of interpretations of the sophists.

${ }^{6}$ For the sophists' challenge to traditional views about the gods, the truth of inherited myths, and customary moral rules, see M. Gagarin and P. Woodruff, 'The sophists', in P. Curd and D.W. Graham (edd.), The Oxford Handbook of Presocratic Philosophy (Oxford, 2008), 365-82. On their contribution to late fifth-century intellectual culture, see J. Billings and C. Moore (edd.), The Cambridge Companion to the Sophists (Cambridge, forthcoming).

${ }^{7}$ Plato distinguishes the truth-seeking dialectic of the philosopher from the superficially persuasive eristic of the sophist: cf. A. Nehamas, 'Eristic, antilogic, sophistic, dialectic: Plato's demarcation of philosophy from sophistry', HPhQ 7 (1990), 3-16, A. W. Nightingale, Genres in Dialogue: Plato and the Construct of Philosophy (Cambridge, 1995), H. Tell, Plato's Counterfeit Sophists (Washington, DC, 2011). Aristotle is less hostile: he grants that the sophists are important figures in the development of rhetoric, but he too distinguishes the aims and methods of the sophist from those of the philosopher: see J. Poulakos, 'Extending and correcting the rhetorical tradition: Aristotle's perception of the sophists', $P h \& R h 16$ (1996), 35-48.

8 D.L. Blank, 'Socratics versus sophists on payment for teaching', ClAnt 4 (1985), 1-49 and D. Corey, 'The case against teaching virtue for pay: Socrates and the sophists', HPTh 23 (2002), 189-210 analyse Plato's aristocratic disdain at the sophists receiving payment for their teaching.

9 Plato's status as a philosophical authority was decisive in shaping the negative tradition. On the importance of authority in the development of ancient philosophy, see J. Bryan, R. Wardy and J. Warren, 'Introduction: authorship and authority in ancient philosophy', in id. (edd.), Authors and Authorities in Ancient Philosophy (Cambridge, 2018), 1-19. 
sophists within the broad intellectual traditions of Archaic and Classical Greece, even if their emphasis on ethics and political philosophy emerged more strongly than that of the Presocratics. Like many of the Presocratics, the sophists had diverse intellectual interests, from oratory and law to history, literature, and mathematics: they were not, pace Plato, simply interested in the profits of rhetoric and relativism..$^{10}$ It is therefore important not only that we see the sophists as a legitimate part of the early Greek philosophical tradition, but also that we seek to illustrate their relationship to the poetic tradition, which was no less productive than that of the Presocratics.

Moreover, like the epic rhapsodes and lyric, tragic, and comic poets, who competed at poetic festivals throughout the Greek world, the philosophers, whether Presocratics or sophists, presented their ideas in performance and in competition with other thinkers. Heraclitus speaks not of reading other people's books but of 'those whose discourses I have heard' (DK 22 B108), while the metres used by Xenophanes, Parmenides, and Empedocles (dactylic hexameter, elegiac couplet, and iambic trimeter) were the standard metres of public recitation. ${ }^{11}$ As with epic and later dramatic poets, the philosophers travelled from place to place performing their work before (they hoped) large audiences: Xenophanes describes his own ideas as having been 'tossed throughout the land of Greece for sixty-seven years' (DK 21 B8). ${ }^{12}$ As always in Greek culture, performance goes hand in hand with competition and vying for position. In a single remark Heraclitus disparages the wisdom of Hesiod, Pythagoras, Xenophanes, and Hecataeus (DK 22 B40). That is, he targets a poet (Hesiod) and a mythographer (Hecataeus) as well as two of his fellow Presocratics. Pindar boasts that his бopía is superior to that of other poets (cf. Olympian 1.115b-17); similarly, the Presocratics and sophists are rivals in the arena of intellectual excellence.

\section{Language and style}

10 The commonplace idea that the sophists were relativists is false. A case can be made for Protagoras, on the basis of his doctrine that 'Of all things the measure is man: of those that are, that they are; and of those that are not, that they are not' (DK $80 \mathrm{~B} 1$ ), but even in his case there is reason to doubt Plato's relativistic interpretation of his views (Tht. 151e2-152a4, 160d5-e2): see J.P. Maguire, 'Protagoras - or Plato?', Phronesis 18 (1973), 115-38, R. Bett, 'The sophists and relativism', Phronesis 34 (1989), 139-69, at 166-9, N. Denyer, Language, Thought and Falsehood in Ancient Greek Philosophy (London, 1991), 87-94.

${ }^{11}$ The development of writing did not diminish the importance of performance in early Greek philosophy, not least because written texts were often shared through public reading: see M.M. Sassi, The Beginnings of Philosophy in Greece, trans. M. Asuni (Princeton, 2018), 73-81.

12 S. Montiglio, 'Wandering philosophers in Classical Greece', JHS 120 (2000), 86-105, at 92-3 discusses Plato's disparaging presentation of the sophists as 'wanderers' whose travels were not in search of knowledge (like the heroic Odysseus) but merely to sell it. 
The sophists' interest in poetry is manifold, ranging from an awareness of differences in linguistic register to the analysis of particular texts. Let us begin with language and literary style. According to Plato (Phaedrus 267b-c), Protagoras advocated ỏ $\rho$ oćs $\varepsilon 1 \alpha$ ('correctness of language'), which is to be understood as applying not only to the use of particular words and expressions, but also (as we shall see below when we turn to Protagoras' comments on Simonides' Scopas ode) the content and cogency of whole compositions, whether in verse or prose. Such a focus on 'correct language' could be used to expose the weaknesses in an opponent's arguments as well as to showcase Protagoras' own skill as a teacher of political rhetoric.

Intriguingly, ó $\rho$ oć $\pi \varepsilon 1 \alpha$ is understood by a later commentator to mean 'the use of literal expressions; for it was by means of words used literally that Protagoras pursued his discourse, and not by means of comparisons and epithets' (Hermias, Commentary on Plato's Phaedrus 267c). However, as A. Rademaker has pointed out, 'Hermias' gloss, stemming from the fourth century $\mathrm{AD}$, seems influenced by the later tradition, and there is no good evidence that Protagoras aimed at a deliberately unequivocal style'. ${ }^{13}$ Indeed, any such 'literalness' is belied by Plato's parody of Protagoras' style as overblown and full of poeticisms:

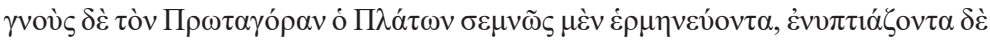

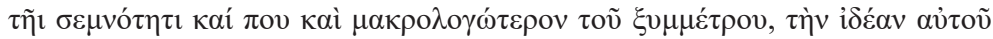

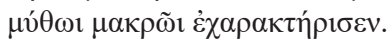

Knowing that Protagoras expressed himself in a pompous style but that he gloried in his pomposity and was in a certain way verbose beyond measure, Plato characterized his style by means of a lengthy myth. (Philostratus, Lives of the Sophists 1.10.4) $)^{14}$

Gorgias, even more than Protagoras, made the use of poetic vocabulary, syntax, and rhythm central to his literary technique. Cicero notes his

paria paribus adiuncta et similiter definita itemque contrariis relata contraria, quae sua sponte, etiamsi id non agas, cadunt plerumque numerose, Gorgias primus invenit ...

parallel clauses, phrases ending with the same sound, antitheses, phrases which, even if one is not aiming at it, on their own most often end with a metrical rhythm - Gorgias was the first to invent these ... (The Orator, 52.175)

${ }^{13}$ A. Rademaker, 'The most correct account: Protagoras on language', in J.M. Van Ophuijsen, M. van Raalte and P. Stork (edd.), Protagoras of Abdera: The Man, His Measure (Leiden, 2013), 87-111, at 100 n. 32.

14 The sophists and their sources are cited here throughout in the translation of A. Laks and G.W. Most, Early Greek Philosophy, Vol. VIII: Sophists, Part I and Early Greek Philosophy, Vol. IX: Sophists, Part II (Cambridge, MA, 2016).

Araucaria. Revista Iberoamericana de Filosofia, Política, Humanidades y Relaciones Internacionales, año $22, \mathrm{n}^{\circ} 44$. Segundo semestre de 2020. Pp. 285-302. ISSN 1575-6823 e-ISSN 2340-2199 https://dx.doi.org/10.12795/araucaria.2020.i44.13 


\section{And Philostratus remarks that}

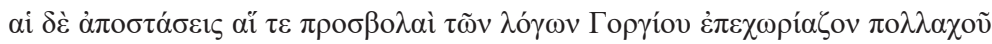

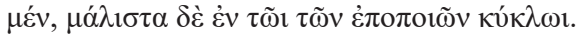

The detached phrases and the asyndetic sentences typical of Gorgias' speeches were often used, especially in the circle of the poets. (Letters 73 )

He is said to have 'used poetic words for the sake of ornament and solemnity' (Philostratus, Lives of the Sophists 1.9.2), a practice mirrored by his fellow sophists Antiphon and Lycophron (see Pollux, Onomasticon 2.76 and Aristotle, Rhetoric 3.3.1405b34-7 for their use of poetic terms). Gorgias' poetic and metaphorical style influenced not only later orators (cf. Dionysius of Halicarnassus, Lysias 3), but also the historian Thucydides (Marcellinus, Life of Thucydides 36) and the tragedian Agathon (Plato, Symposium 198c), but was forcefully condemned by Aristotle:

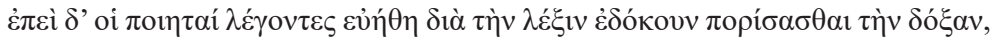

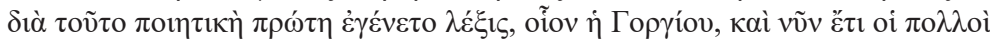

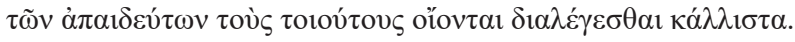

Since it was because of their style that the poets seemed to have acquired their fine reputation even though what they said was simpleminded, for this reason in the beginning style was poetic, like that of Gorgias. And even now many uncultured people think that men like this are speaking in the finest way possible. (Rhetoric 3.1.1404a24-7)

But as Aristotle's grudging acknowledgement shows, many people were impressed by Gorgias' ability to meld prose and poetry and some were willing to pay to learn how to do it. Purists might reject his style as 'entirely vulgar and overly pompous and "not far from certain dithyrambs"” (Dionysius of Halicarnassus, Lysias 3.4, quoting Plato, Phaedrus 238d), and Plato has his (virtuously) unshowy Socrates reject 'prettified speeches' in favour of 'everyday words' (Apology 17b-c), ${ }^{15}$ but audiences in Athens and elsewhere enjoyed Gorgias' antithetical style, with its matching clauses, assonances, word-endings, and rhymes.

15 For Socrates' relationship to the sophists, and his conversations with them as presented by Plato and Xenophon, see S. Broadie, 'The sophists and Socrates', in D. Sedley (ed.), The Cambridge Companion to Greek and Roman Philosophy (Cambridge, 2003), 73-97, L. Edmunds, 'What was Socrates called?', CQ 56 (2006), 414-25, C.C.W. Taylor, 'Socrates the sophist', in L. Judson and V. Karasmanis (edd.), Remembering Socrates (Oxford, 2006), 157-68, A.G. Long, 'Socrates and sophists', in S. Golob and J. Timmermann (edd.), The Cambridge History of Moral Philosophy (Cambridge, 2017), 15-27. 


\section{The value of poetry}

The important role of poetry in education was recognized by Protagoras:

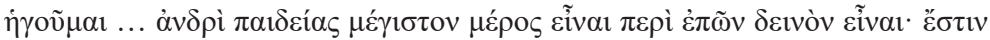

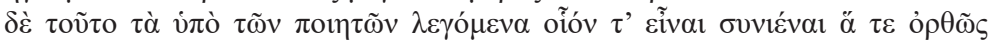

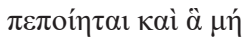

Protagoras: I think ... that for a man the most important part of education consists in being expert concerning poems; and this means to be able to understand what is said correctly by the poets and what is not ... (Plato, Protagoras 338e-339a)

To illustrate his ability as a literary critic, Plato's Protagoras offers a critical reading of a poem by Simonides (fr. $542 P M G$ ):

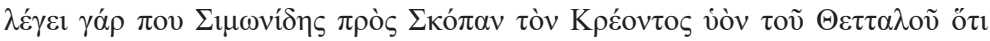

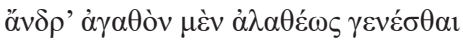

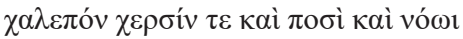

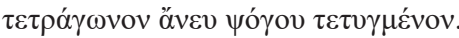

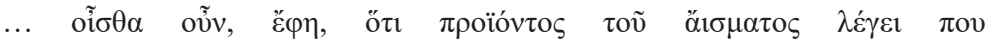

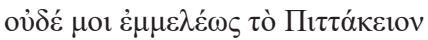

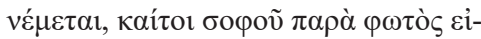

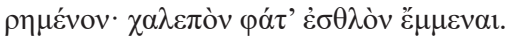

Simonides says somewhere to Scopas, the son of Creon of Thessaly, that

For a man to become truly good

is difficult, four-square in hands, feet, and mind, constructed without any blemish.

... Then you know, he said, that as the ode proceeds he says somewhere,

Nor does Pittacus' assertion seem well-said to me,

although it was spoken by a wise man.

He said that it is difficult to be good. (Protagoras 339a-c)

Protagoras goes on to argue that Simonides contradicts himself in first saying that it is difficult to become good and then criticizing Pittacus, one of the 'Seven 'Sages', for asserting that it is difficult to be good (Protagoras 
339c-e). ${ }^{16}$ By detecting this alleged inconsistency in Simonides' poem, Protagoras illustrates how he might triumph in rhetorical debate by exposing contradictions in his opponent's arguments. ${ }^{17}$ The passage may also imply that Protagoras saw the discussion and criticism of poetic passages as a rhetorical technique capable of being used in actual speeches in the courts or assembly. In any case, his division of speech acts into request, question, answer, and command (cf. Diogenes Laertius 9.53-4) enabled him to fault the opening of the Iliad (no less), 'Sing, goddess, of the wrath of Achilles', on the basis that instead of making a request, as he should, the poet utters a command (a criticism of Homer rejected as irrelevant pedantry by Aristotle, Poetics 19.1456b15-18). Protagoras' penchant for pointing out the good and bad in poetry did not endear him to everyone:

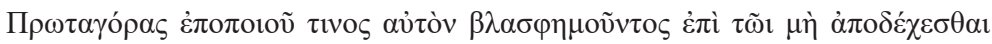

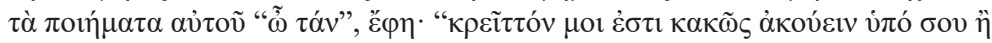

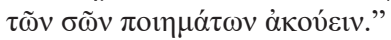

When some poet was insulting him because he did not approve of his poems, Protagoras said, 'My dear man, I would rather hear your slanders than your poems.' (Vatican Gnomology 468)

Less negatively, the sophist Lycophron is said to have praised the lyric poets (Alexander of Aphrodisias, Commentary on Aristotle's Sophistic Refutations, 118.30-119.3), and the anonymous Dissoi Logoi (or 'Double Arguments') cites tragic verses ( $\operatorname{Tr} G F$ Adesp. fr. 26), including some by Aeschylus (fr. 301-2 R), to enhance its arguments on justice and injustice. As it happens, the same section of the Dissoi Logoi ends by asserting that 'the poets certainly do not compose their poems for the sake of truth, but for the sake of people's pleasure' (3.17), and the interrelated issues of poetry's purpose and its effect upon the audience are combined in Gorgias' famous analysis of dramatic illusion:

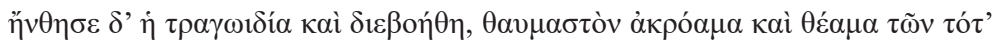

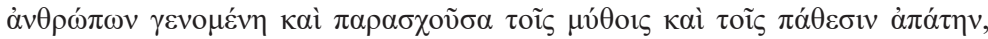

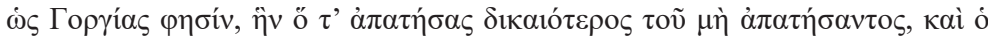

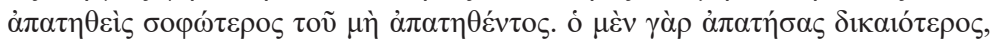

${ }^{16}$ On the structure and content of Simonides' poem, see F. Budelmann, Greek Lyric: A Selection (Cambridge, 2018), 214-16, and for Plato's use of both Simonides and Protagoras, see A. Carson, 'How Not to Read a Poem: Unmixing Simonides from Protagoras', CPh 87 (1992), 110-30.

${ }^{17}$ R. Pfeiffer, History of Classical Scholarship: From the Beginnings to the End of the Hellenistic Age (Oxford, 1968), 33 observes, 'This kind of critical examination of the poet's single words and their proper meaning (for example $\varepsilon \mu \mu \varepsilon v \alpha \iota$ and $\gamma \varepsilon v \varepsilon \dot{\sigma} \sigma \alpha_{1}$ ) is in the Sophist's view the most important mental training; it is necessary for a young man to be trained in this way because it helps him to

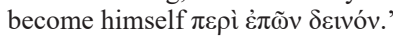




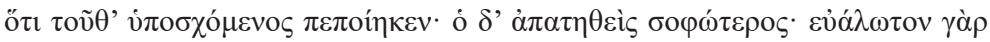

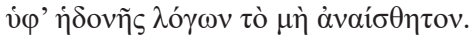

Tragedy flourished and was acclaimed - it was a marvellous spectacle for the ears and eyes of the men who lived in those times, which produced by means of stories and suffering 'a deception', as Gorgias says, 'in which the one who deceives is more just than the one who does not deceive, and the one who is deceived is more intelligent than the one who is not deceived.' For the one who deceives is more just because he has done what he has promised, and the one who is deceived is more intelligent, for whoever is not insensible is easily captured by the pleasure of words. (Plutarch, On the Glory of the Athenians $5.348 \mathrm{c})$

Gorgias' description of tragic storytelling as a form of 'deception' foregrounds its ability to persuade the audience of the reality of its (dramatic) world, and suggests another reason why the study of poetry, with its many techniques for commanding belief, would be particularly useful for sophists (and their pupils) pursuing the systematic study of persuasion and argument. ${ }^{18}$

\section{Myth and fable}

Although Greek poetry from Homer onwards has an important philosophical dimension, there is a considerable difference between the methods of the poets and those of the philosophers. For the philosophical analysis offered by the Presocratics and the sophists was unlike the explanations offered by such thinkers as Homer and Hesiod, whose 'accounts of things (when they gave them) were primarily mythical rather than rational'. ${ }^{19}$ The distinction between philosophers or physiologoi on the one hand, and mythologoi or poets on the other, is found already in Plato and is made even more explicit by Aristotle, as befits his tendency to classify and systematize (Metaphysics 983b27-84a3). Yet we should be cautious about articulating the distinction in terms of myth and reason. As Aristotle himself remarks, after saying that men began to philosophize out of wonder, 'even the myth-lover is in a sense a philosopher, for myth is composed of wonders' (Metaphysics 982b1820). Moreover, philosophers (especially Plato) continued to use myths, and numerous quotations from the poets, despite their hostility to them. ${ }^{20}$ Thus,

\footnotetext{
${ }^{18}$ In Gorgias' theory of rhetoric, persuasion itself is a form of deception and a speech's success is fundamentally tied to its poetic qualities: see W.J. Verdenius, 'Gorgias' doctrine of deception', in G. B. Kerferd (ed.), The Sophists and their Legacy (Wiesbaden, 1981), 116-28.

19 P. Curd, 'The Presocratics as philosophers', in A. Laks and C. Louguet (edd.), Qu'est-ce que la philosophie présocratique? (Lille, 2002), 115-38, at 115-16.

20 See K.A. Morgan, Myth and Philosophy from the Presocratics to Plato (Cambridge, 2000), 17.
} 
while the idea of 'myth' as an untrue or unprovable story that was opposed to rational argument did gain currency among intellectuals in the fifth century (e.g. Herodotus 2.23, Thucydides 1.22.4), the modern view of Greek culture as passing (in a logical and rational progression) from mythos to logos (classic statement in Nestle) is too rigid. ${ }^{21}$

Protagoras, for example, is presented as asking his audience if they would like him to deliver his speech as a mythos or as a logos:

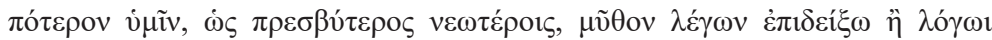
$\delta 1 \varepsilon \xi \varepsilon \lambda \theta \omega \dot{v}$;

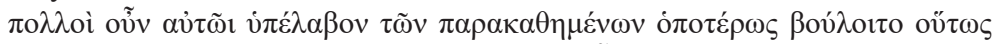

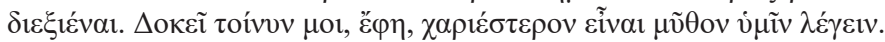

Protagoras: ... would you rather that I explain by telling you a story (mythos), as an older man speaking to younger ones, or by expanding it in an argument $(\log o s)$ ?

Many of those who were sitting there suggested that he should expound it in whichever of the two ways he preferred. 'Well', he said, 'it seems to me to be more agreeable for me to tell you a story.' (Plato, Protagoras 320c; cf. Gorgias 523a)

Protagoras' myth, with its focus on Prometheus' gifts to humans (fire and cleverness/sophia, both stolen from the gods) and Zeus's bestowal of shame (aidōs) and justice (dikē) in order to prevent mutual destruction, is a new version of a familiar story, building upon earlier poetic accounts of the development of human civilization, especially that of Hesiod (cf. Works and Days 47-201), whose persona as a wise man lecturing his feckless younger brother is evoked by the phrase 'as an older man speaking to younger ones'.22

Similarly Hesiodic is Prodicus' use of moral fable in his tale of Heracles' choice between virtue and vice (as paraphrased by Xenophon, Memorabilia 2.1.21-34). ${ }^{23}$ The adolescent Heracles is met at a crossroads by two women representing these divergent life-choices and must choose which

${ }^{21}$ W. Nestle, Vom Mythos zum Logos: Die Selbstentfaltung des griechischen Denkens von Homer bis auf die Sophistik und Sokrates (Stuttgart, 1940); see R.L. Fowler, 'Mythos and logos', JHS 131 (2011), 45-66 (with copious bibliography on a vast topic).

22 On Hesiod and early Greek philosophy, see S. Tor, Mortal and Divine in Early Greek Epistemology: A Study of Hesiod, Xenophanes and Parmenides (Cambridge, 2017), 52-103. For Protagoras' originality in creating the myth, see B, Manuwald, 'Protagoras' myth in Plato's Protagoras: fiction or testimony?', in J.M. Van Ophuijsen, M. van Raalte and P. Stork (edd.), Protagoras of Abdera: The Man, His Measure (Leiden, 2013), 163-77. A. Brancacci, 'La pensée politique de Protagoras', RPhA 30 (2012), 59-85 discusses its relationship to Protagoras' political thought in general.

${ }_{23}$ M. Kuntz, "The Prodicean "choice of Herakles": a reshaping of myth', CJ 89 (1993), 163-8 underlines Prodicus' reworking of traditional story-patterns; D. Sansone, 'Heracles at the Y', JHS 124 (2004), 125-42 and id., 'Xenophon and Prodicus' choice of Heracles', CQ 65 (2015), 371-7 argues that Xenophon's paraphrase is close to Prodicus' original, which was a display piece aimed at attracting new fee-paying pupils.

Araucaria. Revista Iberoamericana de Filosofia, Política, Humanidades y Relaciones Internacionales, año $22, \mathrm{n}^{\circ} 44$. Segundo semestre de 2020. Pp. 285-302. ISSN 1575-6823 e-ISSN 2340-2199 https://dx.doi.org/10.12795/araucaria.2020.i44.13 
road to take. Vice promises him 'the most pleasant and easy road', full of every physical and sensuous pleasure, with no work or hardship involved. Virtue, by contrast, condemns the emptiness and disgrace of the voluptuous life, and argues that only a life of honest toil can lead to true happiness. Heracles rejects the 'short and easy road' of vice and embraces the 'long and hard road' of virtue. Though Prodicus was criticized for his radical views on the origins of the gods (DK 84 B5), the morality inculcated here is wholly conventional. ${ }^{24}$

\section{Arguing with poets}

Gorgias' display speeches in praise of Helen and in defence of Palamedes represent perhaps the most striking engagement with poetic tradition in the surviving works of the sophists. In his Encomium of Helen Gorgias deploys his antithetical style, with its matching clauses, assonances, word-endings, and rhymes, to overturn 'the credence given to poets' (2). Gorgias assumes the traditional story of Helen's elopement with Paris to Troy, but composes a defence of her conduct that is no less daring or ingenious than Euripides' revision of the myth in his Helen (produced in 412 BC; Gorgias' work cannot be dated $\left.{ }^{25}\right)$. Gorgias denies outright Helen's responsibility for her actions by depicting her as the victim of various forms of coercion: the gods, the power of her abductor Paris, his persuasive speech, or love itself (where erōs is construed as an external force not subject to Helen's will). Significantly, Gorgias' description of the power of speech includes an account of poetry:

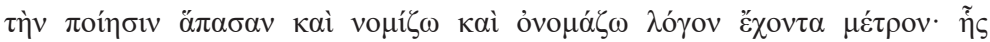

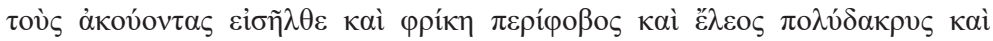

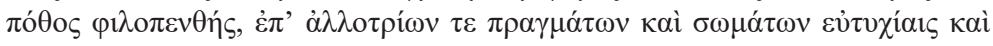

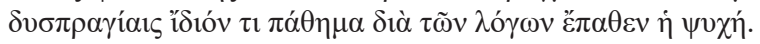

I consider all poetry to be speech (logos) that possesses metre, and I give it this name. Those who hear it are penetrated by a terribly fearful shuddering, a much-weeping pity, and a yearning that desires grief, and on the basis of the fortunes and misfortunes of other people's actions and bodies their soul is affected, by an affection of its own, by the medium of words. (Encomium of Helen, 9)

${ }^{24}$ R. Mayhew, Prodicus the Sophist (Oxford, 2011), 184 comments that the speech 'leaves open the possibility that Prodicus believed in (or did not deny) the existence of, say, the god(s) of the presocratic philosophers'.

${ }^{25}$ On the date of Gorgias' Encomium, see D.M. MacDowell, Gorgias: Encomium of Helen (Bristol, 1982), 12.

Araucaria. Revista Iberoamericana de Filosofia, Política, Humanidades y Relaciones Internacionales, año 22, $\mathrm{n}^{\circ} 44$. Segundo semestre de 2020. Pp. 285-302. ISSN 1575-6823 e-ISSN 2340-2199 https://dx.doi.org/10.12795/araucaria.2020.i44.13 
The irresistible effects of poetry upon its audience underline the challenge facing Gorgias, who must overcome centuries of poetry condemning Helen's infidelity. ${ }^{26}$ He concludes:

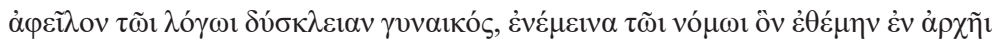

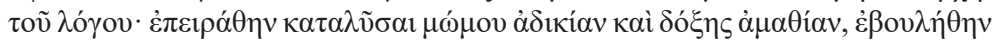

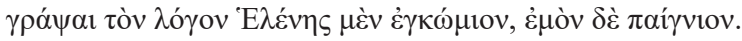

By my speech I have removed the ill repute of a woman, I have abided by the norm that I established at the beginning of my speech. I have attempted to annul the injustice of blame and the ignorance of opinion, I wished to write a speech that would be an encomium for Helen and an amusement for me. (Encomium of Helen, 21)

His self-proclaimed success in clearing the reputation of Greek culture's most notorious adulteress proves (and advertises) his own skills as an orator and teacher of rhetoric.

In contrast to Helen, all earlier poetic treatments of Palamedes agree on his essential innocence and present him as unjustly framed by Odysseus for betraying his fellow Greeks to the Trojans. ${ }^{27}$ Thus the novelty of the Defence of Palamedes lies not so much in its central thesis as in its ingenious method of defence, which is to refute Odysseus' charge by showing that the elements required to prove it true - that Palamedes communicated with the enemy, exchanged oaths, hostages, or valuables with them, and colluded with others without being seen - are all in fact impossible (6-12). Palamedes goes on to show that all imaginable motives - to gain power, wealth, honour, or security - are equally improbable (13-21). Finally, he argues that the accusation itself is self-contradictory in that it presents him as both intelligent and mad:

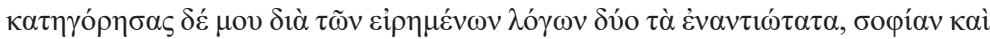

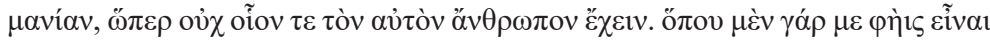

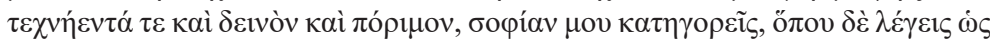

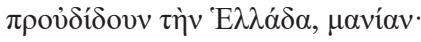

You have accused me, in the speeches I have mentioned, of two things that are completely contrary to one another, craftiness and madness, of which it is not

${ }^{26}$ For the role of emotion as well as reason in Gorgias' account of how persuasion works, see C. Segal, 'Gorgias and the psychology of the logos', HSPh 66 (1962), 99-155. O.V. Bychkov and A. Sheppard, Greek and Roman Aesthetics (Cambridge, 2010), xiv-xv and J.I. Porter, The Origins of Aesthetic Thought in Ancient Greece (Cambridge, 2010), 179-307 present Gorgias' views in relation to other ancient discussions of the emotional effect of art and poetry.

${ }^{27}$ Some sources explain Odysseus' actions on the ground that when he pretended to be mad in order to avoid the Trojan War, Palamedes exposed his deception (e.g. the cyclic epic Cypria, according to Proclus' summary); others foreground Odysseus' jealousy of Palamedes' cleverness and services to the Greeks (e.g. $\Sigma$ Eur. Or. 432, Xen. Mem. 4.2.33). 
possible for the same man to possess both. For you accuse me of craftiness when you say that I am skilled, clever, and resourceful, but of madness when you say that I betrayed Greece. (Defence of Palamedes, 25)

The argument from antinomy, where contradictory qualities are ascribed to the same entity, is one of Gorgias' favourite techniques, ${ }^{28}$ and is used here to

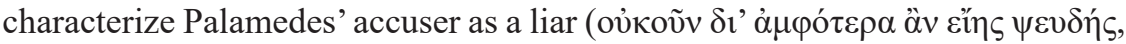
Pal. 26). Thus Gorgias takes a familiar tension in Odysseus' characterization in early Greek literature - his trustworthiness and willingness to deceive (e.g. Iliad 9.308-14, Sophocles, Philoctetes 83-120) - and uses logical argumentation to ground it in a strikingly novel way, and one that avoids appearing to be merely an ad hominem attack. $^{29}$

\section{Conclusion: poetry in the service of philosophy}

Despite the extremely mannered (and easily parodied: Plato, Symposium 194e-197e) style of Gorgias' speeches, and despite his own admission that the Encomium is, at least partly, 'an amusement for myself' (21), his works reflect upon a number of serious philosophical issues, from the power of language to the extent of human responsibility. ${ }^{30}$ Thus the sophists' engagement with the poetic tradition, like that of the Presocratics, is geared primarily to serve their philosophical or didactic goals, even if the aesthetic benefits of poetic language and style must also be acknowledged. Protagoras, for example, uses Simonides' poem to advertise his skill in detecting contradictions, while Gorgias' Palamedes argues that each stage needed for the preparation and commission of his alleged treason was in fact impossible, thereby illustrating the effectiveness of arguing from probability. ${ }^{31}$

${ }^{28}$ In On Not Being, for example, the work's first thesis, 'that nothing exists', is supported by (among other arguments) the claim that 'it is completely absurd for something at the same time to be and not to be' (Sext. Emp. Math. 7.65-7).

29 Personal attacks were of course common in real-life forensic and political oratory and much

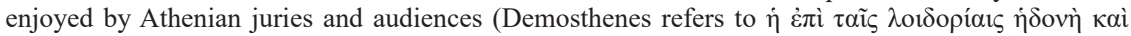

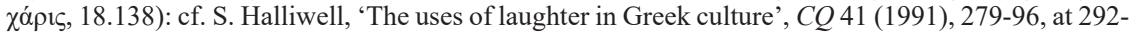
4. Gorgias, however, characterizes Palamedes as taking the moral high ground throughout, avoiding easy attacks on the $\tilde{\tilde{\eta}} \theta$ o $\zeta$ of his opponent. As he says at the end of his address to Odysseus and before his final appeal to the jury, 'Although I would be able to accuse you in turn of having committed many great crimes, old ones and new ones, I do not wish to do so. For I wish to be acquitted of this accusation not because of your evil deeds but because of my good ones' (Pal. 27). 134.

30 See R. Wardy, The Birth of Rhetoric: Gorgias, Plato and their Successors (London, 1996), $25-$

${ }^{31}$ On arguments from probability, see G.H. Goebel, 'Probability in the earliest rhetorical theory', Mnemosyne 42 (1989), 41-53, P. Woodruff, 'Rhetoric and relativism: Protagoras and Gorgias', in A.A. Long (ed.), The Cambridge Companion to Early Greek Philosophy (Cambridge, 1999), 290-310, J. Bryan, Likeness and Likelihood in the Presocratics and Plato (Cambridge, 2012), 78-80. C.W. Tindale,

Araucaria. Revista Iberoamericana de Filosofí, Política, Humanidades y Relaciones Internacionales, año 22, $\mathrm{n}^{\circ} 44$. Segundo semestre de 2020. Pp. 285-302. ISSN 1575-6823 e-ISSN 2340-2199 https://dx.doi.org/10.12795/araucaria.2020.i44.13 
Moreover, the interactions between philosophy and poetry in Archaic and Classical Greece work in both directions. For although Plato sought to drive a wedge between philosophy and poetry (esp. Ion, Republic II-III, X) ${ }^{32}$ poets from Homer and Hesiod onwards show an awareness of the widest range of 'philosophical' (or perhaps better 'intellectual') issues, from the justice of the gods to the origins of human society, so that, in respect of intellectual content, one cannot easily separate the poets from the philosophers. Even Aristotle, in the first detailed report on the Presocratics that we have (Metaphysics 983b-987a), allows that the question of first causes may originate with Homer (Iliad 14.201, 246) and Hesiod (Theogony 116ff.). The sophists' debt to poetic tradition shows this interaction, in the opposite direction, no less clearly. ${ }^{33}$

In conclusion, the sophists' influence on various genres of literature and philosophy is widely acknowledged, but the influence of earlier traditions of poetry and myth on their work is no less important. The sophists recognized poetry's important role in education, and their varied use of poetic language, style, and content in their own teaching was a continuation of this traditional aspect of poetry. They may not have been poet-philosophers in the mould of Xenophanes, Parmenides, and Empedocles, but their work on rhetorical, political, and ethical issues engaged with, and was enriched by, the shared poetic culture of their time.

Reasons's Dark Champions: Constructive Strategies of Sophistic Argument (Columbia, 2010), 61152 analyses the many different forms of argumentation used by the sophists from probability (eikos) and commonplaces (topoi) to the use of character and appeals to justice; D. Spatharas, 'Patterns of argumentation in Gorgias', Mnemosyne 54 (2001), 393-408 considers a similar range of techniques in Gorgias specifically.

32 Cf. E.S. Belfiore, 'Plato's greatest acccusation against poetry', in F.J. Pelletier and J. King Parlow (edd.), New Essays on Plato (Guelph, 1983), 39-62, G.F. Else, Plato and Aristotle on Poetry (Chapel Hill, 1986), T. Gould, The Ancient Quarrel between Poetry and Philosophy (Princeton, 1990), S. Halliwell, 'The subjection of muthos to logos: Plato's citations of the poets', $C Q 50$ (2000), 94-112, Bychkov and Sheppard (n. 25), 5-73, R.S. Liebert, Tragic Pleasure from Homer to Plato (Cambridge, 2017), 120-70.

${ }^{33}$ So too in modern philsophy, where several leading thinkers have grounded their ideas in ancient literature: e.g. M.C. Nussbaum, The Fragility of Goodness: Luck and Ethics in Greek Tragedy and Philosophy (Cambridge, 1986), B. Williams, Shame and Necessity (Berkeley, 1993), A. MacIntyre, After Virtue: A Study in Moral Theory (London, 2007³). 


\section{Works cited}

Belfiore, E. S. 1983. 'Plato's Greatest Accusation Against Poetry', Canadian Journal of Philosophy 13 (Supplementary Volume 9): 39-62.

Bett, R. 1989. 'The Sophists and Relativism', Phronesis 34: 139-69.

Billings, J. and C. Moore eds. forthcoming. The Cambridge Companion to the Sophists, Cambridge.

Blank, D. L. 1985. 'Socratics versus Sophists on Payment for Teaching', ClAnt 4: $1-49$.

Brancacci, A. 2012. 'La pensée politique de Protagoras', $R P h A$ 30: 59-85.

Broadie, S. 2003. 'The Sophists and Socrates', in D. Sedley, ed. The Cambridge Companion to Greek and Roman Philosophy (Cambridge) 73-97.

Bryan, J. 2012. Likeness and Likelihood in the Presocratics and Plato, Cambridge.

Bryan, J., Wardy, R. and J. Warren, 2018. 'Introduction: Authorship and Authority in Ancient Philosophy', in id., eds. Authors and Authorities in Ancient Philosophy (Cambridge) 1-19.

Budelmann, F. 2018. Greek Lyric: A Selection, Cambridge.

Bychkov, O. V. and A. Sheppard, 2010. Greek and Roman Aesthetics, Cambridge.

Carey, C. 2000. 'Old Comedy and the Sophists', in F.D. Harvey and J. Wilkins, eds. The Rivals of Aristophanes: Studies in Athenian Old Comedy (London) 255-64.

Carson, A. 1992. 'How Not to Read a Poem: Unmixing Simonides from Protagoras', CPh 87: 110-30.

Conacher, D. J. 1998. Euripides and the Sophists: Some Dramatic Treatments of Philosophical Ideas, London.

Corey, D. 2002. 'The Case against Teaching Virtue for Pay: Socrates and the Sophists', HPTh 23: 189-210.

Corey, D. 2015. The Sophists in Plato's Dialogues, Albany.

Curd, P. 2002. 'The Presocratics as Philosophers', in A. Laks and C. Louguet, eds. Qu'est-ce que la philosophie présocratique? (Lille) 115-38.

Denyer, N. 1991. Language, Thought and Falsehood in Ancient Greek Philosophy, London.

de Romilly, J. 1992. The Great Sophists in Periclean Athens, trans. J. Lloyd, Oxford.

Dover, K. J. 1968. Aristophanes: Clouds, Oxford.

Edmunds, L. 2006. 'What Was Socrates Called?', CQ 56: 414-25.

Else, G. F. 1986. Plato and Aristotle on Poetry, Chapel Hill.

Fowler, R. L. 2011. 'Mythos and logos', JHS 131: 45-66. 
Gagarin, M. and P. Woodruff, 2008. 'The Sophists', in P. Curd and D.W. Graham, eds. The Oxford Handbook of Presocratic Philosophy (Oxford) 365-82.

Goebel, G. H. 1989. 'Probability in the Earliest Rhetorical Theory', Mnemosyne 42: 41-53.

Goldhill, S. 2002. The Invention of Prose, Oxford.

Gould, T. 1990. The Ancient Quarrel between Poetry and Philosophy, Princeton. Guthrie, W. K. C. 1971. The Sophists, Cambridge.

Halliwell, S. 1991. 'The Uses of Laughter in Greek Culture', CQ 41: 279-96.

Halliwell, S. 2000. 'The Subjection of Muthos to Logos: Plato's Citations of the Poets', CQ 50: 94-112.

Hornblower, S. 2009. 'Intellectual Affinities', in J. S. Rusten, ed. Oxford Readings in Classical Studies: Thucydides (Oxford) 60-88.

Hussey, E. 1972. The Presocratics, London.

Kerferd, G. B. 1981. The Sophistic Movement, Cambridge.

Kuntz, M. 1993. 'The Prodicean "Choice of Herakles”: A Reshaping of Myth', CJ 89: $163-8$.

Laks, A. and G. W. Most, 2016a. Early Greek Philosophy, Vol. VIII: Sophists, Part I, Cambridge, MA.

Laks, A. and G. W. Most, 2016b. Early Greek Philosophy, Vol. IX: Sophists, Part II, Cambridge, MA.

Liebert, R. S. 2017. Tragic Pleasure from Homer to Plato, Cambridge.

Long, A. G. 2017. 'Socrates and Sophists', in S. Golob and J. Timmermann, eds. The Cambridge History of Moral Philosophy (Cambridge) 15-27.

MacDowell, D. M. 1982. Gorgias: Encomium of Helen, Bristol.

MacDowell, D. M. 1995. Aristophanes and Athens, Oxford.

MacIntyre, A. 20073. After Virtue: A Study in Moral Theory, London.

Maguire, J. P. 1973. 'Protagoras - or Plato?', Phronesis 18: 115-38.

Manuwald, B. 2013. 'Protagoras' Myth in Plato's Protagoras: Fiction or Testimony?', in J.

M. Van Ophuijsen, M. van Raalte and P. Stork, eds. Protagoras of Abdera: The Man, His Measure (Leiden) 163-77.

Mayhew, R. 2011. Prodicus the Sophist, Oxford.

McCoy, M. 2008. Plato on the Rhetoric of Philosophers and Sophists, Cambridge.

Montiglio, S. 2000. 'Wandering Philosophers in Classical Greece', JHS 120: 86-105.

Morgan, K. A. 2000. Myth and Philosophy from the Presocratics to Plato, Cambridge.

Nehamas, A. 1990. 'Eristic, Antilogic, Sophistic, Dialectic: Plato’s Demarcation of Philosophy from Sophistry', $H P h Q 7:$ 3-16. 
Nestle, W. 1940. Vom Mythos zum Logos: Die Selbstentfaltung des griechischen Denkens von Homer bis auf die Sophistik und Sokrates, Stuttgart.

Nightingale, A. W. 1995. Genres in Dialogue: Plato and the Construct of Philosophy, Cambridge.

Nussbaum, M. C. 1986. The Fragility of Goodness: Luck and Ethics in Greek Tragedy and Philosophy, Cambridge.

Osborne, C. 1998. 'Was Verse the Default Form for Presocratic Philosophy?', in C. Atherton, ed. Form and Content in Didactic Poetry (Bari) 23-35.

Pendrick, G. J. 2002. Antiphon the Sophist: The Fragments, Cambridge.

Pfeiffer, R. 1968. History of Classical Scholarship: From the Beginnings to the End of the Hellenistic Age, Oxford.

Porter, J. I. 2010. The Origins of Aesthetic Thought in Ancient Greece, Cambridge.

Poulakos, J. 1996. 'Extending and Correcting the Rhetorical Tradition: Aristotle's Perception of the Sophists', $P h \& R h$ 16: 35-48.

Rademaker, A. 2013. 'The Most Correct Account: Protagoras on Language', in J. M. Van Ophuijsen, M. van Raalte and P. Stork, eds. Protagoras of Abdera: The Man, His Measure (Leiden) 87-111.

Sansone, D. 2004. 'Heracles at the Y', JHS 124: 125-42.

Sansone, D. 2015. 'Xenophon and Prodicus' Choice of Heracles', CQ 65: 3717.

Sassi, M. M. 2018. The Beginnings of Philosophy in Greece, trans. M. Asuni, Princeton.

Segal, C. 1962. 'Gorgias and the Psychology of the Logos', HSPh 66: 99-155.

Spatharas, D. 2001. 'Patterns of Argumentation in Gorgias', Mnemosyne 54: 393-408.

Taylor, C. C. W. 2006. 'Socrates the Sophist', in L. Judson and V. Karasmanis, eds. Remembering Socrates (Oxford) 157-68.

Tell, H. 2011. Plato's Counterfeit Sophists, Washington, DC.

Thomas, R. 2000. Herodotus in Context: Ethnography, Science and the Art of Persuasion, Cambridge.

Tindale, C. W. 2010. Reasons's Dark Champions: Constructive Strategies of Sophistic Argument (Columbia).

Tor, S. 2017. Mortal and Divine in Early Greek Epistemology: A Study of Hesiod, Xenophanes and Parmenides, Cambridge.

Verdenius, W. J. 1981. 'Gorgias’ Doctrine of Deception', in G. B. Kerferd, ed. The Sophists and their Legacy (Wiesbaden) 116-28.

Wardy, R. 1996. The Birth of Rhetoric: Gorgias, Plato and their Successors, London.

Warren, J. 2007. Presocratics, Abingdon.

Williams, B. 1993. Shame and Necessity, Berkeley. 
Woodruff, P. 1999. 'Rhetoric and Relativism: Protagoras and Gorgias', in A. A. Long, ed. The Cambridge Companion to Early Greek Philosophy (Cambridge) 290-310. 